\title{
Ctesias in the Achaemenid Persia?
}

\author{
Libor Pruša \\ (Masaryk University, Brno)
}

\begin{abstract}
This paper focuses on the life and works of Ctesias of Cnidus, a Greek physician living at the Achaemenid court during the reign of Artaxerxes II. Ctesias was the author of the important work on Persian history, customs, and court life called Persica. He spent many years in the Achaemenid Empire and summarized his experience and studies in his seminal work. Persica was a very influential discourse on Persia in antiquity even though Ctesias had a notoriously poor reputation. The core of the problem is the veracity of Ctesias' account, his claims of the usage of Persian sources, and his life in the Achaemenid Empire in general. Our main goal is to find possible answers to the stories circulating about his life in the Achaemenid Empire. Later authors criticized Ctesias for telling lies and promoting himself in the books. We will discuss how legitimate their approach is and whether the reputation of Ctesias is deserved. The problem will be studied in three chapters. In the first part of the article, we will take a closer look at the life of Ctesias. We will study the possible reasons for his departure to Persia, how he later managed to work for the King, what occupation and position he held at the court, which places in the Achaemenid Empire he visited and why he left the court. In the second part, we will focus on the sources of his works. Their nature and content varied greatly and influenced his writings differently. In the last part, we will focus on Ctesias' possible knowledge of one or more of the languages spoken at the court. Foreign words also appear in his works and the list of them will be a part of the article.
\end{abstract}

\section{Keywords}

Ctesias; Achaemenid Persia; Persica; Greek historiography 


\section{Introduction}

Ctesias remains an enigmatic person of ancient Greek historiography to this day. The details of his life barely ever appear in the ancient sources except for his stay in the Achaemenid Empire. Ctesias hailed from the city of Cnidus. ${ }^{1}$ This city was located on the peninsula in the southwestern part of Asia Minor, which was at that known as Caria. Although the exact dates of his birth and death cannot be determined, he was born around the half of the fifth century BCE, ${ }^{2}$ and died after 393/2 BCE. The city was famous for its medical school. Ctesias himself was a physician, he studied there and practiced medicine before departing for Persia. After his return from the Achaemenid Empire, he possibly continued practicing medicine and became a historiographer on top of it. It does not look probable that he wrote anything while staying at the royal court. He was the author of several works, none of which apparently focused on medicine despite his profession. The most notable ones are Persica and Indica. As the names suggest, they dealt with the history, ethnography, and geography of Persia and India.

Unfortunately, his works are now lost, ${ }^{3}$ we only have quotes and epitomes in the works of later authors. The highest number of fragments of Ctesias' works appear in the writings of four Greek authors. Thanks to them we have at least a rough idea about the structure and content of Persica and Indica. The first books of Persica are covered mostly by Diodorus Siculus and Nicolaus of Damascus, Photius summarized Persica from book 7 onwards and Plutarch used the last few books of Persica in his Life of Artaxerxes. Indica is summarized in the epitome by Photius. ${ }^{4}$

As a historian, Ctesias was generally considered unreliable. He was even called a self-promoting liar. The most vocal critic was Plutarch: “... even if Ctesias has put a lot of incredible and mad stories into his books ..."; "Ctesias, as it seems, stupendously loves honour ... he always gives himself some space in the narrative." ${ }^{6}$ Arrian did not hold Ctesias in high esteem either: "Ctesias - if anyone considers Ctesias to be a reliable source ..." Ctesias is (unsurprisingly) ridiculed by Aulus Gellius ${ }^{8}$ and Lucian. ${ }^{9}$ His reception was mixed at best already in antiquity and initially did not change much in the

1 Suda, s.v. Kiпoíac.

2 Brown (1978: p. 10) suggests the year 441 BCE, although as he himself adds, it is just "a rough estimate".

3 POxy 2330 is the only fragment of authentic text of any of Ctesias' works preserved to the modern-day. The fragment contains 28 lines. It describes the love story of Stryangaeus and Zarinaia. This tale was a part of the books 4-6 of Persica. This episode is also mentioned by Nicolaus of Damascus (FGrH 90 F5) and Diodorus (2.34.1-5). From these fragments we can deduce how later authors worked with Persica. Both authors significantly reduced the length, offered only a summary, and omitted many details of the love story. The shifts in style are also noticeable. See Bigwood (1986) for more information.

4 See Bigwood (1989).

5 Plu. Art. 1.2.

6 Plu. Art. 13.4.

7 Arr. An. 5.4.2.

8 Gell. 9.4.

9 Luc. VH. 2-4. 
modern-day. ${ }^{10}$ Only in the last decades the fragments of his works are revisited and his records are now accepted in a more positive light, ${ }^{11}$ but some questions about his life and writings remain. The main criticism is related to his inclusion of fairy tales, myths, and various monsters. In addition, some of the parts dealing with the history of Persia are questionable and far from reality. The first part of Persica, known as Assyriaca, covering books 1-6, is for most part a semilegendary account of the Assyrian and the Median Empire. Ctesias also recorded alternative tradition of the life of Cyrus the Great and differs from other sources (Herodotus and Xenophon). Most of the account of Indica is also composed of fantastical stories and reports on mythical animals and strange human tribes. Indica as such contains much more overblown stories than Persica.

On the other hand, he was always criticised for the content, never for his style of writing. He was also very often compared to Herodotus, who was the main authority on the history of Persia. Ctesias knew Herodotus' work very well and even though he was not simply copying him, sometimes it appears that he reacted on Histories and attempted to expose Herodotus as a liar and to create an alternative version of Persian history. ${ }^{12}$ Despite the objections to his historical account, he was still an authority on the history of the Middle East in antiquity, his works were widely quoted and, if nothing else, it looks like they had a high entertainment value.

\section{Ctesias' stay in Persia}

As we already know, Ctesias worked as the physician. After practicing medicine in his hometown, he moved to Persia and later managed to work for a high-profile person of that time - Achaemenid king Artaxerxes II. He also cared for the whole royal family and by his account, it looks like he was close with the King's mother Parysatis. Ctesias thus had a unique opportunity to get to know Persia, or at least the Achaemenid royal court, very closely. He was not a mere visitor to the capital. During his stay he could meet the King himself and his family on a regular basis and observe every detail of the court life. Unlike other Greeks writing about Persia, ${ }^{13}$ he had the greatest potential to inquire into the Persian affairs. Some details of his life at the court are potentially made-up, though.

Ctesias visited the Achaemenid court in the late fifth century BCE. The Achaemenid Empire was ruled by Darius II until 404 BCE, when he was succeeded by his son Artaxerxes II. However, his younger brother Cyrus the Younger made a claim to the throne,

10 Jacoby (1922: p. 2047) summarized the historical value of Ctesias' writings as "gleich Null."

11 For example the introduction and translation of the fragments by Dominique Lenfant (2004), Lloyd Llewellyn-Jones \& James Robson (2010), and Jan Stronk (2010). Also see the article by Eran Almagor (2012).

12 See Marincola (1997: pp. 227-228) for Ctesias' relationship to Herodotus. Photius asserts that he deliberately aimed to discredit Herodotus (Phot. Bibl. 72 §1). Drews (1973: pp. 104-105) supports this view.

13 Persica was a whole genre during the fifth and the fourth century BCE. Ctesias was not a sole author of a book called Persica, as there were five other authors of the books of the same name. For the full list see Lenfant (2007). 
which eventually led to the battle of Cunaxa in 401 BCE, where Cyrus the Younger died. The wife of Darius II and the mother of the warring sons was queen Parysatis. Her relationship to Artaxerxes took a hit, as she supported Cyrus, but she remained an influential figure after she reconciled with Artaxerxes. In the account of Ctesias Parysatis appears to be a driving force behind the decisions made by Darius II and his son, although in the case of Artaxerxes, she faced his wife, Stateira, whose family was executed by Parysatis. The relationship between these two women remained hostile and led to the death of Stateira. Ctesias thus experienced an era full of hostilities and power struggles at the court. An ominous danger at the court and frequent acts of violence are recurring topics in Persica.

Ctesias had quite a long time to get to know Persian history and customs, as it seems that he spent seventeen years in Persia. ${ }^{14}$ We know the year of his departure (398/7 BCE), the date of his arrival remains unknown. By simply counting seventeen years from the mentioned date, we get to the year 415/4 BCE. The length of his stay is disputed, some scholars prefer a shorter span of seven years. The figure seventeen could be an exaggeration made by Ctesias to increase his own credibility or it could be a mistake made by a scribe. ${ }^{15}$ It is possible that he did not spend the whole time at the Persian royal court, but stayed several years at a smaller regional court, probably in Sardis, before he was promoted to work in the King's residence. ${ }^{16}$ It should also be noted that Ctesias was not the only Greek physician working for Persian kings, as there are accounts of at least three others. ${ }^{17}$ This means that Persian kings employed physicians from Greece regularly. ${ }^{18}$

From Diodorus we know Ctesias got to Persia as a prisoner of war. ${ }^{19}$ The details of his capture are not given. There is speculation about Ctesias' involvement in the revolt of Pissuthnes, which took place around the year $415 \mathrm{BCE}$, a possible date of Ctesias' arrival to Persia..$^{20}$ On the other hand, an invitation to work as a physician at the royal court is also a possibility, ${ }^{21}$ especially if we consider the tradition of employing Greek physicians by Achaemenids. We can also combine the possibilities, Ctesias could be captured by one of the governors and later was promoted to work for the King due to his medical knowledge.

There are only two certain dates associated with his presence in Persia. For the first time he appeared in the sources during the battle of Cunaxa (401 BCE). Ctesias stood

14 D.S. 2.34.4.

15 See Brown (1978: pp. 1-4) for more information about his possible arrival in 405/4 BCE. Also see Stevenson (1997: pp. 5-6) for his possible travel to Persia in that year and his seven-year stay. For a possible mistake in the text and the reading as seven instead of seventeen see Bigwood (1978: p. 19).

16 Eck (1990: pp. 431-432); Brown (1978: pp. 8-10).

17 Democedes of Croton served as a physician for Darius I. (Hdt. 3.122-125), Apollonides of Cos during the reign of Artaxerxes I. (Phot. Bibl. $72 \$ 44$ ) and Polycritus of Mendes during the reign of Artaxerxes II., just like Ctesias (Plu. Art. 21.2).

18 A lot of Greeks of different professions were employed by Persians in general. See Brosius (2011).

19 D.S. 2.34.4.

20 Stronk (2004-2005: pp. 102-104) suggests the year 413 BCE as the date of Ctesias' capture by Persians and his subsequent seventeen-year stay; Brown (1978: pp. 7-10).

21 Briant (2002: p. 264). 
on the side of Artaxerxes II. During the battle he even treated the wounds the King had suffered in the fight with his own brother. ${ }^{22}$ Ctesias then himself appeared in his own writings as he describes how he helped the Spartan general Clearchus in the prison after the battle. He also witnessed a hostile relationship between the King's mother Parysatis and the King's wife Stateira which culminated with the poisoning of Stateira by Parysatis. ${ }^{23}$ The second date related to his stay in Persia is the year of his departure 398/7 BCE. Ctesias had other commitments than medicine at that time, as he was sent on a diplomatic mission to Cyprus. During the early fourth century BCE Artaxerxes II backed the preparations of the war against Sparta. It is unclear whether Ctesias was sent there directly by the King or if he modified the letters, so that he could undertake the mission as he states. ${ }^{24}$ It has been suggested that he wrote some of the letters himself ${ }^{25}$ and was not just a courier and had a diplomatic skill needed for this mission. He also supposedly acted as a diplomat on several occasions even before the mission to Cyprus, but his role seems exaggerated. ${ }^{26}$

When an occasion presented itself, Ctesias left Persia for good and went on a mission to Sparta. On the way, he got involved in a trial on Rhodes and only then he returned to his hometown ${ }^{27}$ or possibly even settled in Sparta. ${ }^{28}$ There is no mention of his possible intention to ever return to Persia. After settling in the Greek world again he wrote down his works. The last date related to his life is the year 393/2 BCE. Ctesias refers to the date palms growing around the burial mound of Clearchus eight years after the general was executed. ${ }^{29}$ Here it might appear that he returned to the court or visited the site, but he could have heard the story from a traveller as well. All in all, the mention gives us the year of possible completion of Persica.

How much Ctesias travelled across the Achaemenid Empire and which sites and cities he visited is a question. His occupation would limit his stay to the royal court, and it does not look like he freely roamed across the Empire, unless he was sent on a diplomatic mission. The court itself was not fixed to just one place but moved between several important cities of the Achaemenid Empire. The King and his entourage travelled between them depending on the season of the year, festivals or religious and monarch duties.

22 X. An. 1.8.26.

23 Plu. Art. 19.

24 Plu. Art. 21.4.

25 Lenfant (2004: p. XIV).

26 He was apparently negotiating with Greeks after the battle of Cunaxa (Plu. Art. 13.3-4), but this looks like a fabrication on his part because Plutarch denies his involvement and Xenophon does not mention Ctesias as a diplomat (X. An. 1.7-23). Later, Ctesias took care of Spartan Clearchus acting on behalf of queen Parysatis (Plu. Art. 18.1-4). This can also be an act of self-presentation and showing affection to Spartans. The whole story with Clearchus and the comb resembles the episode during the battle of Thermopylae (Hdt. 7.208). Ctesias also received a ring as proof of friendliness of Spartans from Clearchus. Later he also went to Sparta and possibly met the Spartan messengers in Persia (Phot. Bibl. 72 \$74-75).

27 Lenfant (2004: p. XXIII); Brown (1978: p. 18).

28 Lenfant (2004: pp. XIX-XX).

29 Phot. Bibl. $72 \S 71$. 
These cities were Babylon, Susa, Ecbatana, and Persepolis. ${ }^{30}$ From the fragments it appears that Ctesias spent most of the time in Babylon, as he does not mention other cities. A visit to Susa and Ecbatana is possible because the royal court travelled to these cities every year. ${ }^{31}$ If he visited the core Persian territory, other provinces, or smaller courts is unclear, we can only suspect that he followed the court to any location it moved to. Ctesias could theoretically see Behistun inscription ${ }^{32}$ which is located on the way between Babylon and Ecbatana, however, then he commits a blunder when he assigns the creation of the monument to queen Semiramis instead of Darius I. for an unknown reason. As far as Indica is concerned, even from the fragments, it is obvious that he never visited India, but at least he was an eyewitness of several Indian animals, which were brought to the Persian court. All in all, we do not have any proof of his possible visit to other parts of the Empire, safe from Babylonia. His stay in the Achaemenid Persia would then indicate more of a Babylonian experience rather than a proper Persian one.

As we know the details of Ctesias' life now, we can return to our main point and discuss the trustworthiness of his account. Later authors had objections to his stay at the royal court and from the points mentioned above, it can be said that they were at least partially justified. Ctesias, as it seems, added to his autobiography in Persica acts he had never done or exaggerated the story to portray himself as a person of extreme importance at the court. ${ }^{33}$ As we have seen above, the length of his stay is debatable, his involvement in various diplomatic missions can be dubious, it appears that he was fond of Spartans and Clearchus as Plutarch accuses him. ${ }^{34}$ From the position of physician he suddenly became a right-hand man of queen Parysatis, the King's messenger and diplomat and enjoyed high esteem and riches at the court. However, then he abruptly left when he got a chance. It does not help that all these details suspiciously mirror the life of another physician - Democedes of Croton, "the most skilful physician of his time." Democedes was captured by Persians, then he worked as a physician at the court, treated an injury of Darius I. and later cured the King's wife Atossa. Similarities do not end here, just like Ctesias, Democedes was richly rewarded, enjoyed the favour of the King and his family, and later went on a diplomatic mission ahead of the planned military campaign but escaped and returned to his hometown. Could this be just a coincidence or did Ctesias deliberately portray himself in a similar manner to Democedes? ${ }^{36}$ This episode throws a shade on his role at the court and naturally, his autobiography could be madeup or significantly modified to give his writing more credibility and to promote himself in the book as a protagonist. ${ }^{37}$ While Ctesias definitely visited the Achaemenid Empire

30 Briant (2002: p. 680).

31 For more information about the Persian court see Llewellyn-Jones (2013: pp. 74-95).

32 He mentions the relief in Persica (D.S. 2.13.2). He called the site Bagistanos.

33 See note 26.

34 Plu. Art. 13.7.

35 Hdt. 3.122-125; 129-130; 132-137.

36 Griffiths (1987: p. 48).

37 See Dorati (2011: pp. 88-99). 
and the city of Babylon, his importance at the court appears to be exaggerated. The extent of modifications of his biography cannot be satisfyingly decided on and we are caught between two extremes: trusting the account of his life and explaining the details or exposing him as a fraud, but there is little middle ground, due to the fragmentary form of Persica.

\section{Sources for Ctesias' works}

The life of Ctesias in the Achaemenid Empire is shrouded in mystery and filled with possible self-presentation and exaggeration. Do his claims that he used the Persian sources fare any better? We will discuss them in this chapter. Ctesias used a variety of sources for his writings. The core of the problem is rooted in the preservation of the sources or precisely the lack of thereof. From the remarks of later authors, we know that Ctesias relied both on written and oral sources. It is described how carefully he studied every bit of information and how he made sure that he personally heard all the accounts from Persians themselves. ${ }^{38}$ In case of the written sources, Ctesias claimed that he had access to the royal archives and the royal parchments. ${ }^{39}$ The nature of these sources and even their existence are a matter of discussion. ${ }^{40}$ Ctesias stated that in these archives and parchments Persians recorded their history and the deeds of their kings. ${ }^{41}$ We do not have almost any written sources dealing with Persian history written by the Persians themselves. ${ }^{42}$ This does not mean they never existed, they could have been written on some perishable material, thus vanishing later. However, the existence of narrative written sources in the vein of Greek historiography does not seem likely.

The institution of the royal archives indeed existed, ${ }^{43}$ however, the content of the sources there was different. Persians kept there mostly administrative records of the Empire. They followed their predecessors and recorded every bit of administrative and economic information ${ }^{44}$ on clay tablets, or eventually on perishable material. There are many types of documents that could have been kept in the archives: economic records, such as lists of delivered goods, loans, purchases, and contracts; edicts or other legal

38 D.S. 2.32.4; Phot. Bibl. $72 \S 1$.

39 Basilikai anagrafai (D.S. 2.22.5.) and basilikai diftherai (D.S. 2.32.4.).

40 For more information see Llewellyn-Jones \& Robson (2010: pp. 58-61); Stronk (2007: pp. 37-40); Briant (2002: p. 889); Cawkwell (2005: pp. 13-15). Cawkwell and Stronk are more open to possible existence of some written sources - Stronk's suggestion "absence of proof does not equal proof of absence" (Stronk 2007: p. 38) is surely plausible, he even adds a circumstantial evidence for the existence of the archives, but in the end, this still leads us to nothing. Briant writes that these archives contained administrative records, while Jacoby denied the existence of any similar documents (Jacoby 1922: p. 2047).

41 D.S. 2.32 .4

42 The sole exception is Behistun inscription.

43 See Pedersén (1998: pp. 183-190, 213-219) for the archives and libraries from Babylon and the Persian area.

44 See Kuhrt (2007: pp. 763-824) for the Persian administrative records. 
documents issued by kings, day-to-day records, possibly also astronomical diaries. ${ }^{45}$ Persians kept the transcriptions of the texts of the monuments as well, ${ }^{46}$ which is the best candidate for Ctesias' supposed study of the written sources. Except for these transcriptions, hardly any of these documents contained much information about the history of Persia, if any at all. On the other hand, maybe Ctesias only tried to strengthen the veracity of his account by simply mentioning the institutions, where the Persians kept their important records, even though he never actually read them or he relied on them only marginally at best. ${ }^{47}$ Once again, this could be just one of his self-promoting claims.

The aforementioned sources contained mostly dry "data", a far cry from the nature of Ctesias' work. Persica is very vivid and more rooted in the oral tradition. It is not much surprising, since there was a strong tradition in the Middle East to transmit history and other tales through spoken word rather than to write anything down. ${ }^{48}$ This leaves us in a difficult spot because we are not able to check the veracity of Ctesias' account and we should use his works with caution. With almost no Persian sources dealing with their own history to study, we are not able to determine, whether Ctesias' reputation of the poor historian in antiquity is fully justified or not. In case of the oral tradition, there was likely not just one transmitter, who told Ctesias everything about Persian history, but many different individuals from the court. Ctesias even mentions queen Parysatis as his source. ${ }^{49}$ He could have possibly gathered information from scribes and officers, ${ }^{50}$ who could probably describe to him the content of the records in the archives, thus solving the question how Ctesias managed to obtain and use the royal parchments. Other accounts have their origin in the tales of merchants and travellers, ${ }^{51}$ gossip from the court, as well as songs and stories about distant past of Persia and earlier history. ${ }^{52}$ While a majority of his work is composed of a hear-say, Ctesias also claims that he was an eyewitness of certain events, ${ }^{53}$ but as we have discussed above, Ctesias would not shy away from giving himself an important role in the narrative.

What is the content of Persica then? If the epitomes and quotes are sufficient proof, the book was a very strange mixture of stories from the court, tales about ancient empires, Ctesias' own observation, hear-say, and rumours about important persons at the court, sometimes sprinkled with some actual history and ethnographical or geographical passages. There is almost no information on the running of the court itself. Recurring themes are violence, murders, intrigues, overall decadence. Ctesias was even

45 Examples from Pedersén (1998: pp. 214-216).

46 Darius ordered to transcribe the text of Behistun inscription on clay tablets and parchments (DB $§ 70)$. Ctesias could refer to these versions.

47 Waters (2017: p. 19).

48 Llewellyn-Jones \& Robson (2010: p. 57).

49 Phot. Bibl. $72 \S 11-13$.

50 See Drews (1973: p. 107).

51 This is the case especially for Indica. See Nichols (2011: pp. 21-27).

52 Llewellyn-Jones \& Robson (2010: p. 63).

53 Ctesias himself appears in the last few books of Persica, during the account of the reign of Artaxerxes II. We do not know whether these parts were written in the first person or not. 
accused of creating a traditional European view on Orient. ${ }^{54}$ Love stories, plotting, and romance frequently break the narrative ${ }^{55}$ there are powerful eunuchs and strong queens everywhere. Persica could be a predecessor of ancient Greek novel..$^{56}$ Persica has been described as a string of novellas as well. ${ }^{57}$ All of these elements are thrown into the continuous narrative of the Assyrian, Median and Achaemenid Empire. Even though Ctesias put a lot of digressions into his account, he at least offers us an outline of the Achaemenid Empire. He is generally reliable when he describes the events and people living in his lifetime, ${ }^{58}$ but then falls into semi-mythical accounts in the first books of Persica. His palace stories could reflect the difficulties of life at the court and his own experience of these events, which he either saw happening or discussed with eyewitnesses. ${ }^{59}$ Sometimes we should accept the fact that we do not have a better source. ${ }^{60}$ Here it seems that Ctesias once again could exaggerate a lot of facts, but maybe he did not even have to, as the court life itself offered him enough material. The tales he heard from certain individuals, whoever they were, are possibly genuine Persian stories combined with his own observation. The low reliability of his historical accounts is thus likely rooted in the not-so-reliable oral tradition. Simultaneously, his study of written sources appears to be out of the question. Nonetheless, his knowledge of the institution could raise his credibility by default.

The last problem of the sources is the actual Ctesias' audience. His writings were not intended to be read by Persians. Thus, Ctesias could freely modify the facts and add the most embellished tales to please and entertain the Greeks. However, he could be more serious in his approach as well and his fantastical stories and animals could be picked out by later authors instead of the more realistic accounts. With the lack of Persian sources and no works of Ctesias preserved in full form, it is difficult to say to what extent Ctesias simply wrote down Persian stories, events of court life, palace intrigues and tales about the kings of the past or made them up and modified them to suit his narrative. While it is easy to discard Ctesias as a useless historian, our perception of his works is affected by his reputation among the later authors, as they clearly favoured other writers (e.g. Herodotus), and the disappearance of his texts.

54 Sancisi-Weerdenburg (1987: pp. 43-44).

55 Marincola (1997: p. 22).

56 See Stronk (2010: pp. 36-51).

57 Gera (1993: p. 209); Llewellyn-Jones \& Robson (2010: pp. 68-76).

58 See Schmitt (2011: pp. 369-371). The names mentioned by Ctesias are very close to those found on the tablets from the Babylonian area from that era.

59 See Lewis (1977: pp. 21-22); Stevenson (1997: pp. 45-46, 80-81); Lenfant (2004: pp. CXV-CXXVIII) for a more positive reception of his stories from the court.

60 Cook (1985: p. 206); Karttunen (1997: p. 636). 


\section{Persian language}

Ctesias' sources also bring up the question of his potential knowledge of foreign languages. At the court he could encounter many different languages - Old Persian, Aramaic, Elamite, Akkadian and various other languages from any region of the Empire. ${ }^{61}$ It is perfectly possible that Ctesias learned Old Persian or any other language used by the royal family and officers. ${ }^{62}$ Aramaic as the lingua franca of the Achaemenid Empire is also an option. ${ }^{63}$ For a physician, it would be extremely impractical to rely on an interpreter all time and not to communicate with the patients directly. With an understanding of the language without a mediator, Ctesias could listen to tales, songs and stories about Persian history and get the information from his sources. Furthermore, it is hard to imagine that after seventeen years (or at least seven) he would not be able to speak any foreign languages. ${ }^{64}$ On the other hand, his access to the texts in the royal archives does not mean that he read anything as we have already discussed. More likely Ctesias debated with the scribes, who interpreted the contents of the cuneiform tablets for him. ${ }^{65}$ It is difficult to imagine a Greek learning a cuneiform script, as it required a long study and for Ctesias it would not be important to learn anyway. Nevertheless, he stayed in Persia for a long enough time to be able to learn a spoken form of Aramaic or Old Persian.

In the fragments several words of foreign origin appear from time to time, which are all usually described as Persian words. These isolated words, however, do not indicate that Ctesias knew Persian on the level of a native speaker or even on any lower lever. Still, as we have pointed out above, Ctesias was not a common visitor and his occupation required at least some knowledge of a foreign language. The words in the following paragraph appear in the fragments of Persica and Indica. They usually do not have a direct Greek equivalent, so their use is mostly practical. Meaning, Ctesias could intentionally spice his works with some foreign words occasionally. ${ }^{66}$ We can only assume that there were more foreign words in Ctesias' works. All of them, of course, appear in a modified Greek form.

Some of the foreign words appear quite frequently in other sources such as satrapes, paradeisos, and parasang. ${ }^{67}$ On the other hand, some of the following words are hapax legomena (for example kriokranoi), appearing only in Ctesias' account, or they are for the first time mentioned by Ctesias (for example martichora). Several of the words re-

61 Not all of them could be necessarily spoken languages at that time (Elamite, Akkadian), but their written forms were still used for administration purposes.

62 Waters (2017: p. 11); Llewellyn-Jones \& Robson (2010: pp. 55-56); Stronk (2010: pp. 21-22).

63 See Bae (2004: pp. 8-15); Stronk (2010: p. 22).

64 There are examples of Greeks learning Persian (Th. 1.138.1; Hdt. 6.29). Although it was very uncommon among the Greeks, it was not unachievable for them. See Miller (1997: pp. 131-133) for general Greek knowledge of the Persian language.

65 Waters (2017: p. 11).

66 Llewellyn-Jones \& Robson (2010: p. 56).

67 Satrapes means a governor, paradeisos means a garden or a park, parasang was a Persian unit of measurement. It is equal to about thirty stadia (Hdt. 5.53) or about five and half kilometres. 
fer to persons. Zoganes was "fake-king" ruling during one of the festivals at the Achaemenid court. ${ }^{68}$ Word azabarites ${ }^{69}$ is also related to an office and it means "Commander of a Thousand." 70 The last two words, referring to a person, are pisagas ${ }^{71}$ and angaros. $^{72}$ Some words are related to Persian realia: sarapis, ${ }^{73}$ kriokrano $^{74}$ and kidaris. ${ }^{75}$ Three words refer to an animal or a plant: rhyntakes is a species of bird ${ }^{76}$ Ctesias then mentions famous monster martichora ${ }^{77}$ and a mysterious tree called siptachora. ${ }^{78}$ Ctesias also explains the etymology of the name Cyrus. ${ }^{79}$

\section{Conclusion}

In this article, we have discussed the details of the life of Ctesias of Cnidus and his writings. We are still missing many important facts about his life and his works and their reception is affected by later authors. Ctesias had a great opportunity to get to know Persia, the royal family, and the court very closely, but his life in Persia is still largely unknown to us. He does not appear in the sources very frequently, and when he does, it is usually in a form of self-presentation. His role at the court was likely not that important as he made it to be, and he freely added some exaggerated stories about his life. Despite the modified autobiography, it is clear he visited the Achaemenid Empire and potentially met the most important people of the court and gathered a good amount of information about Persian history. He claimed the usage of written sources, but seemingly never read them since he only simply mentioned a Persian institution to increase his credibility. It is apparent he foremostly relied on oral tradition and various stories circulating at the court. Ctesias recorded gossip from the court, love tales, the most intriguing stories

68 Ath. 14.44. Zoganes was a mock king wearing royal dress and insignia and ruling for five days. The festival was called Sacaea and was somewhat similar to Roman Saturnalia, where the roles of slaves and masters were reversed. This custom was of Babylonian origin (Briant 2002: p. 726).

69 Phot. Bibl. 72 §49. From Persian hazarapatiš.

70 Briant (2002: p. 258). Llewellyn-Jones \& Robson (2010: p. 56) have "Head of the royal bodyguard."

71 Phot. Bibl. 72 \$43. A Persian term for a lepper.

72 Nic. Dam. FGrH 90 F4.4-5. A Persian term for a King's messenger or a royal courier.

73 Hsch. Lex. s.v. бapámıc. A Persian court dress. It was purple with a white stripe in the middle. See Collins (2012: pp. 388-389).

74 Phot. Bibl. $72 \S 1$. Probably some sort of a balcony or a roof-space decorated with ram-like elements (Llewellyn-Jones \& Robson 2010: pp. 56, 170-171).

75 Nic. Dam. FGrH 90 F66.45. A variant of the word (kitaris) also appears (Phot. Bibl. 72 \$50). A Persian royal headdress, an upright tiara. See Berndt (2020) for more information.

76 Plu. Art. 19.3. This bird, according to the Persians and Ctesias, was full of fat and fed solely on wind and dew.

77 Ael. NA. 4.21. "Man-eater." A monster with the head of a human, the body of a lion and the tail of a scorpion. Since antiquity it is associated with a tiger (Paus. 9.21.4). See Nichols (2011: pp. 104-105).

78 Phot. Bibl. $72 \S 36,40$. The tree produced amber according to Ctesias. It is linked to Kynokephaloi, as they ate the fruit of these trees. Siptachora should mean "sweet."

79 Plu. Art. 1.3. Cyrus means "Sun." 
about kings, queens, and officers. He also recorded traditional accounts about ancient kings and empires, though these records do not have high historical value. Some of his remarks are still the best source we have, or even the only one we have. We cannot satisfyingly say whether Ctesias deliberately modified the tales. His experience from the court influenced his writing, but was the court really that violent, hostile, and decadent as depicted by him? With no original text of Persica and the lack of Persian sources, we can hardly determine the trustworthiness of his account. The stories of people living during his lifetime are probably real and plausible, but when he describes events of more distant past, he becomes less and less reliable. This cannot be entirely his fault because his transmitters were just not experts on history. During his stay, he probably needed to learn a spoken form of Aramaic or Old Persian and some Persian words made their way to his works, although we do not have any direct proof of his knowledge of any foreign language.

Both Persica and Indica can be easily criticised, but they are still one of the most unique and most intriguing works of antiquity, as Ctesias combined the elements of two different cultures. His works are a mixture of Greek curiosity, Ctesias' own observations, Persian tales about their own past, and various gossip and events from the court. The overall fantastical nature of the writing is, however, closer to the side of entertainment rather than to serious historiography. We should also not forget that he was Greek and was writing for a Greek audience. The alteration of the facts and exaggeration for the sake of shock is a distinct possibility as well as the enmity of the authors quoting him who could choose the most bizarre elements of Persica and Indica. Nonetheless, through the eyes of Greek physician turned historian, we have obtained many interesting remarks on the Achaemenid Persia.

\section{Bibliography}

Almagor, E. (2012). Ctesias and the Importance of his Writings Revisited. Electrum, 19, 9-40.

Bae, Ch. (2004). Aramaic as a Lingua Franca During the Persian Empire (538-333 B.C.E.). Journal of Universal Language, 5, 1-20.

Berndt, S. (2020). The Upright Tiara of Persian Kings. In A. P. Dahlén (Ed.), Achaemenid Anatolia: Persian presence and impact in the Western Satrapies 546-330 BC (pp. 65-79). Uppsala: Department of Archaeology and Ancient History, Uppsala University.

Bigwood, J. M. (1978). Ctesias as Historian of the Persian Wars. Phoenix, 32, 19-41.

Bigwood, J. M. (1986). POxy 2330 and Ctesias. Phoenix, 40, 393-406.

Bigwood, J. M. (1989). Ctesias' Indica and Photius. Phoenix, 43, 302-316.

Briant, P. (2002). From Cyrus to Alexander. A History of the Persian Empire (transl. P. T. Daniels). Winona Lake, IN: Eisenbrauns.

Brosius, M. (2011). Greeks at the Persian court. In J. Wiesenhöfer, R. Rollinger, \& G. B. Lanfranchi (Eds.), Ktesias' Welt (pp. 69-80). Wiesbaden: Harrassowitz Verlag.

Brown, T. S. (1978). Suggestions for a Vita of Ctesias of Cnidus. Historia, 27, 1-19.

Cawkwell, G. (2005). The Greek Wars. The Failure of Persia. Oxford: Oxford University Press. 
Collins, A. (2012). The Royal Costume and Insignia of Alexander the Great. American Journal of Philology, 531, 371-402.

Cook, J. (1985). The Rise of the Achaemenids and Establishment of their Empire. In I. Gershevitch (Ed.), The Cambridge History of Iran (Vol. 2; pp. 200-291). Cambridge: Cambridge University Press.

Dorati, M. (2011). Lo storico nel suo testo: Ctesias e la sua 〈biografia〉. In J. Wiesenhöfer, R. Rollinger, \& G. B. Lanfranchi (Eds.), Ktesias' Welt (pp. 81-110). Wiesbaden: Harrassowitz Verlag.

Drews, R. (1973). The Greek Accounts of Eastern History. Cambridge, MA: Center for Hellenic Studies.

Eck, B. (1990). Sur la vie de Ctésias. Revue des Etudes Grecques, 103, 409-434.

Gera, D. L. (1993). Xenophon's Cyropaedia. Style, Genre, and Literary Technique. Oxford: Clarendon Press.

Griffiths, A. (1987). Democedes of Croton. A Greek Doctor at the Court of Darius. In H. Sancisi-Weerdenburg, \& A. Kuhrt (Eds.), Achaemenid History, II: The Greek Sources (pp. 37-51). Leiden: Brill.

Jacoby, F. (1922). Ktesias. In Paulys Realencyclopädie der classischen Altertumswissenschaft (Vol. XI,2; cols. 2032-2073). Stuttgart: Druckenmüller.

Karttunen, K. (1997). Ctesias in Transmission and Tradition. Topoi, 7(2), 635-646.

Kuhrt, A. (2007). The Persian Empire. A Corpus of Sources from the Achaemenid Period (II Vols). London - New York: Routledge.

Lenfant, D. (2004). Ctésias de Cnide. La Perse, L'Inde, Autre Fragments. Paris: Les Belles Lettres.

Lenfant, D. (2007). Greek historians of Persia. In J. Marincola (Ed.), A Companion to Greek and Roman Historiography (pp. 200-209). Oxford: Blackwell.

Lewis, D. M. (1977). Sparta and Persia lectures delivered at the University of Cincinnati, Autumn 1976, in memory of Donald W. Bradeen [by] David M. Lewis. Leiden: E. J. Brill.

Llewellyn-Jones, L. (2013). King and Court in Achaemenid Persia 559 to 331 BCE. Debates and documents in ancient history. Edinburgh: Edinburgh University Press.

Llewellyn-Jones, L., \& Robson, J. (2010). Ctesias' History of Persia: Tales of the Orient. London - New York: Routledge.

Marincola, J. (1997). Authority and Tradition in Ancient Historiography. Cambridge: Cambridge University Press.

Miller, M. (1997). Athens and Persia in the Fifth Century BC: A Study in Cultural Receptivity. Cambridge: Cambridge University Press.

Nichols, A. (2011). Ctesias. On India, and Fragments of His Minor Works. London: Bristol Classical.

Pedersén, O. (1998). Archives and Libraries in the Ancient Near East 1500-300 B.C. Bethesda: CDL Press.

Sancisi-Weerdenburg, H. (1987). Decadence in the Empire of Decadence in the Sources? From Source to Synthesis: Ctesias. In H. Sancisi-Weerdenburg (Ed.), Achaemenid History, I: Sources, Structures and Synthesis (pp. 33-45). Leiden: Brill.

Schmitt, R. (2011). Ktesias' Namen stecken voller Geheimnisse. Die Persika als Quelle der altiranischen Anthroponomastik. In J. Wiesenhöfer, R. Rollinger, \& G. B. Lanfranchi (Eds.), Ktesias' Welt (pp. 367-384). Wiesbaden: Harrassowitz Verlag.

Stevenson, R. B. (1997). Persica. Greek Writing about Persia in the Fourth Century BC. Edinburgh: Scottish Academic Press. 
Stronk, J. (2004-2005). Ctesias of Cnidus: From Physician to Author. Talanta, 36-37, 101-122.

Stronk, J. (2007). Ctesias of Cnidus, a Reappraisal. Mnemosyne, 60, 25-58.

Stronk, J. (2010). Ctesias' Persian History, I: Introduction, Text, and Translation. Düsseldorf: Wellem Verlag.

Waters, M. (2017). Ctesias' Persica and its Near Eastern Context. Madison: University of Wisconsin Press.

Mgr. et Mgr. Libor Pruša / liborprusa.jr@seznam.cz

Department of Classical Studies

Masaryk University, Faculty of Arts

Arna Nováka 1, 60200 Brno, Czech Republic 